\title{
Analityk jako pisarz i biograf. Psychograficzna twórczość Izydora Sadgera a psychoanaliza literatury
}

Agnieszka Więckiewicz

TEKSTY DRUGIE 2019, NR 1, S. 402-420

DOI: 10.18318/td.2019.1.27 | ORCID: 0000-0002-2119-7215

$\mathbf{M}$ arian Albiński, pisząc o znaczeniu freudyzmu dla badań literackich, zauważył, że „pierwszym zagadnieniem, z którym zetknęła się psychoanaliza poza obserwacją zjawisk tzw. przyrodzonych, było dzieło twórcze i twórcza fantazja"1. Najwcześniejszym śladem zainteresowania Zygmunta Freuda literaturą był tekst poświęcony analizie snów w noweli Gradiva Wilhelma Jensena, napisany latem 1906 roku i opublikowany rok później w wydawnictwie Hellera ${ }^{2}$ oraz odczyt wygłoszony 6 grudnia 1907 roku zatytułowany Pisarz ifantazjowanie, w którym refleksja nad dziełami kultury splatała się z teorią psychoanalityczną ${ }^{3}$. Wkrótce, korzystając

1 M. Albiński Stan badań psychoanalitycznych w zakresie twórczości literackiej, "Przegląd Humanistyczny” 1923 nr 2, s. 3.

2 S. Freud Obłęd isny w "Gradivie"Wilhelma Jensena, w: tegoż Sztuki plastyczne i literatura, przeł. R. Reszke, KR, Warszawa 2009.

3 Streszczenie wystąpienia Freuda zostało opublikowane w wiedeńskim dzienniku "Die Zeit" dzień po wykładzie. Odczyt w formie artykułu ukazał się jednak dopiero w 1908 roku w "Neue Revue" - zob. S. Freud Sztuki plastyczne i literatura, s. 283. 
z narzędzi wypracowanych przez Freuda, również jego najbliżsi uczniowie zajęli się badaniem związku nieświadomego z twórczością artystyczną. Praca nad metodą badania psychologii twórców oraz pierwsze próby pisarstwa psychograficznego często prowadziły do sporów dzielących wiedeńskie środowisko psychoanalityków.

Freudyści szczególnie wiele dyskusji poświęcili dziełom autorstwa Izydora Sadgera, jednego z pierwszych wpółpracowników Zygmunta Freuda, już na wczesnym etapie swej pracy naukowej poświęcającego się pisaniu psychografii poetów. To właśnie jego studia, czerpiące jeszcze z języka XIX-wiecznej psychiatrii, przekształciły zastany model interpretowania psychologii twórców. W pierwszej dekadzie XX wieku psychoanalitycy odeszli od XIX-wiecznego gatunku patografii, aby wypracować nowy sposób pisania o poetach, nazywany przez nich „psychografią” i opierający się na teorii freudowskiej ${ }^{4}$. Publikacje Sadgera, krytykowanego i niedocenianego w Wiedeńskim Towarzystwie Psychoanalitycznym ${ }^{5}$, w dużej mierze ujawniają interdyscyplinarny charakter pracy freudystów, łączących w swej refleksji wiedzę medyczną z refleksją humanistyczną. Przypadek wiedeńskiego neurologa jest szczególnie interesujący. Na co dzień zajmował się on pracą kliniczną oraz pisał specjalistyczne artykuły medyczne, a jednocześnie poświęcał się tworzeniu psychologicznych portretów poetów, publikowanych na łamach niemieckojęzycznych czasopism kulturalnych ${ }^{6}$. Co istotne, większość szkiców jego autorstwa, które legły u podstaw wielu wydanych później monografii, regularnie ukazywały się

4 W większości prac poświęconych historii ruchu psychoanalitycznego Sadger pojawia się jedynie kontekstowo. W polskiej literaturze przedmiotu - zob. L. Magnone Emisariusze Freuda. Transfer psychoanalizy do polskich sfer inteligenckich przed drugq wojnq światowq, Universitas, Kraków 2016, s. 78-83; W. Marzec Zapomniani protoplaści. Archeologia refleksji o sadyzmie i masochizmie, "Teksty Drugie” 2011 nr 4, S. 231. Obszerny i jedyny artykuł poświęcony relacji wiedeńskiego lekarza z Freudem oraz wpływie jego teorii na twórcę psychoanalizy napisała niemiecka badaczka Ulrike May - zob. U. May The Early Relationship between Sigmund Freud and Isidor Sadger. A Dream (1897) and A Letter (1902), "Psychoanalysis and History” 2003 No. 5 (2), s. 119-145. Dzięki staraniom Alana Dundesa w 2005 roku opublikowano biografię Freuda autorstwa Sadgera, przez długi czas uznawaną za zaginioną - zob. I. Sadger Recollecting Freud, ed. by A. Dundes, trans. J.M. Jacobsen, University of Wisconsin Press, Wisconsin-Madison 2005.

Por. A. Dundes Introduction, w: I. Sadger Recollecting Freud, s. xv-xxxv.

6 Spis najważniejszych publikacji Sadgera, w tym jego najwcześniejszych artykułów z końca lat 80. XIX wieku - zob. E. Mühlleitner Biographisches Lexikon der Psychoanalyse. Die Mitglieder der Psychologischen Mittwoch-Gesellschaft und der Wiener Psychoanalytischen Vereinigung 1902-1938, Diskord, Tübingen 1992, s. 284-285. 
drukiem w czasie poprzedzającym powstanie najwcześniejszych tekstów Freuda o literaturze.

\section{Psychoanaliza w badaniach literackich i pierwsze polemiki z językiem psychiatrii}

Pierwsi freudyści, pisząc o sztuce i literaturze, wskazywali na związek dzieła artystycznego z nieświadomością. Tworzenie służyć miało spełnianiu „fantastycznych nieuświadomionych życzeń"7 oraz przedstawianiu życia popędowego „w różnorodnych postaciach fantastycznych"8. Psychoanalitycy szczególnie chętnie badali twórczość romantyczną. Lektura dzieł J.W. Goethego, Heinricha von Kleista, Franza Grillparzera, Friedricha Hebbela czy Konrada Meyera pozwoliła im przyjrzeć się figurze bohatera romantycznego - jednostce przekraczającej społeczne normy, skonfliktowanej z otoczeniem oraz oscylującej na granicy zdrowia i szaleństwa. Alina Kowalczykowa, odwołując się do tradycji romantycznej, zauważyła, że jeśli ofiarami szaleństwa padają podmioty szczególnie wrażliwe, to obłęd traktować można jako znak wewnętrznego bogactwa i dowód na niszczący wpływ społeczeństwa na twórczą jednostkę, nie zaś na jej upośledzenie`. Eksperymenty romantyków z osiąganiem innych stanów świadomości, takich jak trans czy hipnoza, pozwalały im przemawiać „językiem nierozumu”, szaleństwo zaś okazywało się punktem dojścia indywidualizmu artysty i sposobem na diagnozowanie własnej epoki ${ }^{\mathbf{1 0}}$.

Anita Całek, rekonstruując historię gatunku biografii naukowej, zwróciła uwagę na charakterystyczne dla XIX wieku postrzeganie geniuszu jako ściśle związanego z chorobą psychiczną. Badaczka podkreśliła, że: „natchnienie porównywano do napadów choroby psychicznej, wyszukiwano też nienormalne reakcje i «podejrzane» zachowania u osób wybitnych"11. Dla rozwijającej się wówczas psychiatrii istotna była relacja między osobą twórcy, jego biografią oraz artystyczną osobowością. Ówcześni lekarze i psychiatrzy tworzyli

7 M. Albiński Stan badań psychoanalitycznych w zakresie twórczości literackiej, s. 3.

8 Tamże, s. 3.

9 A. Kowalczykowa Ciemne drogi szaleństwa, Wydawnictwo Literackie, Kraków 1978, s. 14.

10 Tamże, s. 13.

11 A. Całek Biografia naukowa. Od koncepcji do narracji. Interdyscyplinarność, teorie, metody badawcze, Wydawnictwo UJ, Kraków 2013, s. 81. 
narracje o obłąkanych, za pomocą których próbowali przełożyć język szaleństwa na dyskurs medyczny ${ }^{12}$. Wchodząc w rolę biografów, szczególnie chętnie analizowali mało znane okresy życia wielkich twórców, w których doszukiwali się momentu przekształcenia geniuszu w szaleństwo.W ten sposób oddzielali normę od patologii, jednostkę chorą od zdrowej.

Jeżeli w badaniach szaleństwa XIX-wieczna psychiatria sprowadzała artystę do przypadku patologicznego, psychoanaliza starała się opisać związek między procesem twórczym a nieświadomością. Odmienny stosunek freudyzmu do relacji sztuki i szaleństwa dobrze widać na przykładzie zestawienia ról pisarza i lekarza, zaproponowanym przez Freuda. W studium Obłęd i sny $w$ "Gradivie” Wilhelma Jensena zauważył on, że autor noweli przedstawił poprawne studium psychiatryczne i, tak jak lekarz, podjął się objaśnienia patologicznych stanów psychicznych ${ }^{13}$. Według autora Totemu i tabu zarówno psychoanalityk, jak i pisarz, choć korzystają z odmiennych metod, czerpią w istocie z jednego źródła ${ }^{14}$. Freud twierdził, że praca psychoanalityka: „polega na świadomej obserwacji nienormalnych procesów psychicznych przebiegających u innych ludzi”15, pisarz zaś: „zwraca uwagę na nieświadomość we własnej duszy, nasłuchuje jakie tkwią w niej możliwości rozwoju i użycza im formy wyrazu artystycznego, miast tłumić je świadomą krytyką"16. Inaczej niż lekarz, pisarz przekłada efekt autoanalizy na tekst, nie musi też dostosowywać go do ram języka naukowego. Według Freuda pisarz nie tłumi swych uczuć „świadomą krytyką", a tym samym zyskuje przewagę nad analitykiem, zmuszonym wybierać między naukowością a autobiografią, artystyczną kreacją a medyczną praktyką ${ }^{17}$.

Wychodząc od analogii między pracą pisarza a dziecięcym fantazjowaniem, Freud wykorzystał teorię psychoanalityczną do badań literaturoznawczych. Idąc za jego przykładem, kolejni członkowie Środowego Towarzystwa Psychologicznego zajęli się badaniem kultury na wzór metody wyłożonej w Objaśnianiu marzeń sennych, zgodnie z którą opisywali wpływ snów na twórczość literacką i artystyczną, same dzieła tłumacząc zaś szczegółami

12

15 Tamże.

16 Tamże.

17 Tamże. 
z biografii twórców. $\mathrm{O}$ związku nieświadomego z procesem twórczym i psychologii artysty najwcześniej pisał Ernest Jones, Otto Rank, Izydor Sadger, Wilhelm Stekel, Karl Abraham, Fritz Wittels oraz Theodor Reik ${ }^{\mathbf{1 8}}$. W prowadzonych badaniach korzystali oni z trzech różnych modeli interpretacyjnych. Pierwszy w dużej mierze polegał na analizie postępowania fikcyjnych postaci pochodzących z dzieł wybranych twórców - w ten sposób przedmiotem badań stał się król Edyp, Lady Makbet, Hamlet czy Don Juan. Kolejny typ publikacji dotyczył związku sztuki z nieświadomymi procesami psychicznymi oraz terapeutycznym wymiarem tworzenia. Ostatni pozwalał psychoanalitykowi wejść w rolę pisarza i poświęcić się tworzeniu psychologicznej biografii wybranego twórcy. Do środowiska wiedeńskich psychoanalityków model pisarstwa psychograficznego wprowadził Sadger, który literaturą zajmował się już w czasie, kiedy Freud pracował nad Objaśnianiem marzeń sennych i czekał na wydanie Studiów nad histerią. Rozpoczynając współpracę ze Środowym Towarzystwem Psychologicznym w 1906 roku, wiedeński neurolog był praktykującym lekarzem interesującym się nowymi metodami terapii (zawłaszcza hydroterapią ${ }^{19}$ ), a zarazem autorem licznych artykułów poświęconych twórczości poetów, z całą pewnością czytanych przez Freuda ${ }^{20}$.

18 E. Jones Das Problem des Hamlet und Ödipus-Komplex, Deuticke, Leipzig-Wien 1911; O. Rank Das Inzest-Motiv in Dichtung und Sage. Grundzüge einer Psychologiedes dichterischen Schaffens, Deuticke, Leipzig-Wien 1912; Der Künstler. Ansätze zu einer Sexual-Psychologie, Internationaler Psychoanalytischer Verlag, Leipzig-Wien 1918; I. Sadger Konrad Ferdinand Meyer. Eine pathographisch-psychologischeStudie , "Grenzfragen des Nerven- und Seelenlebens" Tom 59, Bergmann, Wiesbaden 1908; Heinrich von Kleist. Eine pathographisch-psychologische Studie , "Grenzfragen des Nerven- und Seelenlebens" Tom 70, J.F. Bergmann, Wiesbaden 1910; Friedrich Hebbel. Ein psychoanalytischer Versuch, "Schriften zur angewandten Seelenkunde” Tom 18, Deuticke, Wien 1920; Aus dem Liebesleben Nicolaus Lenaus, Deuticke, Lepizig-Wien 1925; W. Stekel Dichtung und Neurose. Bausteine zur Psychologie des Künstlers und des Kunstwerkes, Bergmann Verlag, Wiesbaden 1909; K. Abraham Traum und Mythos. Schriften zur angewandten Seelenkunde, VDM Verlag dr Müller e.K., Saarbrücken 2013; F. Wittels Tragische Motive. Das Unbewußte von Held und Heldin, Egon Fleischel, Berlin 1911; Theodor Reik Flaubert und seine Versuchung des heiligen Antonius. Ein Beitrag zur Künstlerpsychologie, J.C.C. Bruns, Minden 1912.

19 Wkrótce po uzyskaniu dyplomu Wydziału Medycznego Uniwersytetu Wiedeńskiego (1891) Sadger rozpoczął współpracę z pismem Wilhelma Winternitza (1834-1917) „Blätter für klinische Hydroterapie und verwandte Heilmethoden", należał również do Gesellschaft für physikalische Therapie in Wien, w ramach którego współpracował z Maxem Kahane.

Jak dowiodła May, wbrew wcześniejszemu twierdzeniu Didiera Anzieu, sen Freuda o stylu "norekdalskim" odnosił się do artykułu Sadgera z 1897 roku Das Wunder vom denkenden Eiwießi potwierdzał zaznajomienie twórcy psychoanalizy z wczesną twórczością Sadgera poświęconą przede wszystkim Ibsenowi - zob. U. May The Early Relationship between Sigmund Freud and 


\section{Freudowski patograf. Sadger i psychoanaliza pisarza}

Pierwsze patografie Izydor Sadger opublikował na długo przed poznaniem Zygmunta Freuda²1. W 1899 roku ukazał się obszerny artykuł jego autorstwa poświęcony Goethemu ${ }^{22}$. W kolejnych latach współpracował z monachijską gazetą „Allgemeine Zeitung”, na łamach której zamieszczał teksty o psychopatologii jednostki twórczej na przykładzie Henrika Ibsena ${ }^{23}$. W ciągu pierwszych dziesięciu lat XX wieku opublikował zaś trzy portrety psychologiczne poświęcone wielkim poetom: Konradowi Ferdinandowi Meyerowi, Nikolasowi Lenauowi oraz Heinrichowi von Kleistowi. W tym samym czasie pracował nad studium o Friedrichu Hebbelu, które ukazało się dopiero w 1920 roku. Wczesne artykuły wiedeńskiego neurologa dotyczyły psychicznych schorzeń twórców i bliskie były klasycznej patografii - gatunkowi wprowadzonemu i rozwiniętemu przez Cesarego Lombroso i Paula Moebiusa. W większym stopniu przypominały one medyczne opisy przypadków (typowe dla ówczesnej psychiatrii) niż niewiele późniejsze psychoanalityczne studia Ranka, Jonesa czy Stekela.

Sadger z teorią Freuda zapoznał się podczas jego wykładów na Uniwersytecie Wiedeńskim w latach 90. XIX wieku. Wcześniej wzorem dla niego był przede wszystkim Moebius. Urodzony w Lipsku filozof i lekarz przez całe życie zajmował się pisaniem biografii wybitnych postaci kultury z perspektywy psychiatry i neurologa. Swe studia, popularne wśród pierwszych psychoanalityków, poświęcił m.in. Jean-Jacques'owi Rousseau, J.W. Goethemu, Arthurowi Schopenhauerowi, Friedrichowi Nietzschemu oraz Robertowi Schumannowi. W ostatnich latach życia pracował nad psychologicznym portretem Charlesa Darwina. Podobnie jak traktaty Moebiusa, tak i dzieła Lombroso, poświęcone związkom geniuszu i szaleństwa oraz wpływom zaburzeń psychicznych na kreatywność, były dobrze znane uczestnikom spotkań Środowego Towarzystwa Psychologicznego.

Isidor Sadger, s. 119-123; por. S. Freud Objaśnianie marzeń sennych, przeł. R. Reszke, KR, Warszawa 2015 , s. 258.

Najwcześniejszy tekst Sadgera dotyczył niemieckiego pisarza Gerharta Hauptmanna - zob. I. Sadger Gerhard Hauptmann. Von einem Nervenpathologen , „Allgemeine Zeitung” 1894 nr 142-143.

I. Sadger War Goethe eine pathologische Erscheinung? , Deutsche Revue über das gesamte nationale Leben der Gegenwart", Stuttgart 1899.

I. Sadger Henrik Ibsen: Rosmersholm. Eine psychiatrisch-ästhetoische Studie, „Allgemeine Zeitung" $1894 \mathrm{nr}$ 195-198; Ibsens Gespenster. Eine ästhetisch-pathologische Studie, „Allgemeine Zeitung" 1894 nr 274, 229; Ibsens Frau mom Meere. Ein pathologisch-mystische Studie , Allgemeine Zeitung" 1894 nr 250-252; Nikolas Lenau. Ein pathologisches Lebensbild, "Allgemeine Zeitung" $1895 \mathrm{nr} 250-252$. 
Przypominające rozszerzone opisy przypadków, klasyczne patografie utrzymane były w stylu raportu $\mathrm{z}$ analizy ${ }^{24}$. Na podstawie materiału biograficznego poszczególnych pisarzy oraz ich twórczości autorzy starali się zdiagnozować u twórców konkretne schorzenia psychiczne, traktując bohaterów pisanych tekstów jak swoich pacjentów. Zgodnie z myślą Michaela Foucaulta typowa dla XIX wieku psychiatryczna narracja o chorym stanowiła przedłużenie reżimu dyscyplinarnego, w którym to nie władca był przedmiotem oglądu, lecz nieustannie kontrolowany poddany ${ }^{25}$. Krzysztof Wolański zauważa, że figura przypadku, centralna dla ówczesnej medycyny klinicznej, funkcjonowała w charakterze „kroniki klinicznego spojrzenia” i odzwierciedlała władzę lekarza nad pacjentem oraz jego wyłączne prawo do interpretacji. W pracach Moebiusa czy Richarda Krafft-Ebinga próżno szukać zrozumienia i empatii dla analizowanych. Ponadto to, co chore, uznawane było przez nich za niemoralne. Homoseksualizm i onanizm (dwie kwestie szczególnie chętnie podejmowane w patografiach) stygmatyzowano jako perwersje, zrównując osąd moralny z etycznym.

Według Foucaulta psychoanaliza jedynie pozornie zmniejszyła dystans między lekarzem a pacjentem. Francuski filozof podkreślił, że:

Jako postać alienująca, lekarz okazuje się punktem kluczowym psychoanalizy. Może dlatego, że [...] psychoanaliza nie słyszy, nie może usłyszeć głosu nierozumu, nie odczytuje znaków niedorzeczności. Może rozwiązywać niektóre formy obłędu - suwerenna praca nierozumu pozostaje dla niej obca. Nie wyzwoli jej ani nie zapisze - tym bardziej nie wytłumaczy, co jest tej pracy esencją. Od końca XVIII wieku życie nierozumu przejawia się już tylko w przebłyskach dzieł takich twórców, jak Hölderlin, Nerval, Nietzsche lub Artaud - w niepojęty sposób wymykają się oni wszelkim uzdrawiającym alienacjom i własną siłą odpierają gigantyczne moralne uwięzienie $[\ldots]^{26}$

Głos nierozumu wymyka się instytucjonalnemu leczeniu psychiatrycznemu i nie może zostać wyrażony w języku XIX-wiecznej psychiatrii. Dla Foucaulta psychoanaliza, mimo swego nowatorstwa, zanurzona była w patologizującym

\footnotetext{
24 Zob. Opisy przypadków, w: Praktyki psychiatrii.

25 M. Foucault Nadzorować i karać, przeł. T. Komendant, Aletheia, Warszawa 2009, s. 187-188.

26 M. Foucault Historia szaleństwa w dobie klasycyzmu, przeł. H. Kęszycka, PIW, Łódź 1987, s. 459.
} 
i umoralniającym języku ówczesnej medycyny. Nie dostrzegł on jednak, że zarówno Freud, jak i jego pierwsi uczniowie byli świadomi zagrożeń medycznej narracji; dlatego też starali się odróżnić teksy własnego autorstwa od klasycznych patografii, a zarazem wypracować nowy model pisarstwa psychograficznego.

W przypadku klasycznej patografii, tak jak i w opisie przypadku, autor zmagał się z problemami zewnętrznymi wobec tekstu. Freud poruszył ów problem w analizie Idy Bauer (Dory):

Publikowanie historii osób, to zadanie, z którym trudno się uporać; [...]. Trudności z jakimi przychodzi mi się tu mierzyć są na poły natury technicznej, na poły zaś wynikają z samej natury sprawy. Jeśli słuszna jest hipoteza, że przyczyny schorzeń histerycznych tkwią w intymnych szczegółach życia psychoseksualnego pacjentów i że symptomy histeryczne stanowią wyraz ich najbardziej sekretnie wypieranych życzeń, wówczas objaśnienie przypadku histerii nie może nie odsłonić owych intymnych szczegółów, nie może nie zdradzić tych sekretów. Zaiste, nie ulega wątpliwości, że chorzy ci nigdy by nie przemówili, gdyby przyszła im do głowy możliwość naukowego wykorzystania ich wyznań, tak jak nie sposób wątpić co do tego, że na próżno prosilibyśmy ich o zgodę na ich publikację. [...] Coż, jeśli o mnie chodzi, uważam iż lekarz bierze na siebie nie tylko obowiązki wobec indywidualnych pacjentów, lecz także wobec nauki, czyli w gruncie rzeczy wobec tak wielu innych chorych, którzy cierpią lub cierpieć będą na tę samą przypadłość. [...] Rzecz jasna nie podaję tu żadnego nazwiska, które pozwoliłoby czytelnikom, z kręgów niefachowych trafić na ślad owej osoby $[\ldots]^{27}$

Konieczność zatajania danych pacjentów nie pozostała bez wpływu na strukturę i charakter tekstu. W narracji tworzonej przez lekarza analizowani stawali się nie tylko produktem psychoanalitycznej interpretacji, lecz i wytworem twórczej fantazji analityka - funkcjonowali w sposób analogiczny do bohatera powieściowego.W przypadku studiów psychograficznych bohater tekstu, a najczęściej i jego autobiograficzne wypowiedzi, były dobrze znane czytelnikom. Dlatego patograf napotykał jeszcze inną trudność. O zagrożeniach

27 S. Freud Fragment analizy pewnej histerii, w: tegoż Histeria i lęk, przeł. R. Reszke, KR, Warszawa 2014, s. 73-74. 
związanych z psychoanalizą twórców Freud pisał w eseju poświęconym Leonardowi da Vinci:

Jeśli medyczne badanie duszy, zadowalające się zazwyczaj skromnym materiałem ludzkim, przystępuje do jednego z wielkich rodzaju ludzkiego, to nie podąża wówczas za motywacją, którą tak często przypisują mu laicy. Nie dąży zatem do tego, by „zaczernić to, co promienne, i wzniosłość unurzać w brudzie", nie czerpie przyjemności ze zmniejszania dystansu pomiędzy ową doskonałością i niedostatkami swych zwykłych obiektów. Nie może ono jednak postępować inaczej, jak tylko uznać, że warto byłoby zrozumieć wszystko, co można dostrzec w owych wzorach, i uważa, że nikt nie jest aż tak wielki, by hańbiło go podporządkowanie się prawom, które z jednakowym rygorem rządzą aktywnością normalną i patologiczną. ${ }^{\mathbf{2 8}}$

Według Freuda psychoanaliza twórcy nie mogła sprowadzać się do zwyczajnego opisu przypadku. Pisanie o uznanym poecie bądź malarzu jako jednostce chorobowej mogło bowiem rodzić sprzeciw czytelników i ostatecznie spotkać się z zarzutem o „kalanie świętości”29. Pisząc Leonarda da Vinci wspomnienia $z$ dzieciństwa, Freud odszedł od ówczesnego rozumienia gatunku patografii jako efektu wyłącznie medycznego spojrzenia na biografię i dzieło artysty. Nie chodziło mu już bowiem o to, aby patologizować przedmiot badania, lecz by, dzięki zastosowaniu metody psychoanalitycznej, ukazać uniwersalne mechanizmy rządzące ludzką psychiką.

\section{Patografia czy psychografia? Ku nowej metodzie badania psychologii twórców} Między 1906 a 1912 rokiem na spotkaniach Środowego Towarzystwa Psychologicznego dyskutowano o ograniczeniach gatunku psychografii oraz nad

28 S. Freud Leonarda da Vinci wspomnienia z dzieciństwa, w: tegoż Sztuki plastyczne i literatura, przeł. R. Reszke, KR, Warszawa 2009, s. 71.

29 Freud powraca do owego tematu w odczycie z 1930 roku wygłoszonym z okazji otrzymania nagrody Goethego: „Przygotowany jestem na zarzut, że my, analitycy straciliśmy prawo do występowania pod patronatem Goethego, ponieważ naruszyliśmy należny mu szacunek, próbując zastosować analizę do niego samego, a tym samym poniżyliśmy tego wielkiego człowieka, degradując go do rangi obiektu analitycznego. Chciałbym tu przede wszystkim zaprzeczyć domniemaniu, iż oznacza to poniżenie czy że o poniżenie nam chodziło" - zob. S. Freud Nagroda Goethego, w: tegoż Sztuki plastyczne i literatura, s. 251. 
psychoanalityczną metodą badania twórczości poetyckiej. Podstawą owych debat były odczyty Sadgera poświęcone związkom choroby i dzieła u Lenaua (1906), Meyera (1907), Kleista (1909) i Hebbela (1912). Krótko po publikacji eseju Freuda poświęconego Gradivie Jensena i na dwa lata przed studium o Leonardzie, 11 grudnia 1907 roku Max Graf, austriacki muzykolog i bliski współpracownik Freuda, przedstawił referat poświęcony metodologii psychologicznego badania poetów. W swej prezentacji członek ŚTP pytał o sens pisania psychografii oraz o poznawczą wartość psychologicznych analiz psychiki artystów ${ }^{30}$. Wyraźnie odróżnił on patografię od portretu psychograficznego opartego na teorii psychoanalitycznej. Według Grafa dotychczasowe dzieła psychiatryczne poświęcone twórcom nie mogły wnieść nic nowego do rozumienia ich twórczości, nie wyjaśniały też kwestii artystycznej kreacji. Błędem Lombroso, twierdził Graf, było sprowadzenie przedmiotu własnej analizy do przypadku patologicznego.W jego pismach każdy poeta stawał się neurotykiem i godnym potępienia przestępcą. Niewiele lepiej traktowano artystów we francuskich środowiskach psychiatrycznych, gdzie dla odróżnienia ich od zwykłych pacjentów ukuto termin dégenérésuperieur. Wiedeński muzykolog postulował odrzucenie gatunku patografii na rzecz psychografii, gdzie psychoanaliza zostałaby połączona z literaturoznawstwem. Sądził on, że siłą metody freudowskiej było wprowadzenie interdyscyplinarnego języka opisu i nieograniczanie się do teorii neuropatologicznych ${ }^{31}$. Graf zauważył, że dzięki szczególnej wrażliwości artystycznej Freud potrafił wznieść się ponad teksty klinicystów, samemu stając się twórcą. Dodał też, że nie każdy psychoanalityk powinien zajmować się psychologią poetów. Jego spostrzeżenie skierowane było przede wszystkim do Sadgera, który, jego zdaniem, nie miał wyobraźni artystycznej. Psychografa od patografa odróżniać miała przede wszystkim delikatność i ostrożność w podejściu do badanego materiału. Sama analiza nie powinna też ograniczać się według Grafa do studiowania autobiografii bądź dzienników. Ważniejsza od rekonstrukcji biografii twórców powinna być lektura ich dzieł - rzeczywistych owoców sublimacji stłumionego popędu, niemożliwego do zrealizowania w ramach społecznie wyznaczonej normy. W akcie twórczym, twierdził Graf, poeta zyskiwał możliwość przezwyciężenia własnych zahamowań. Działalność artystyczna dawała mu też wyjątkową szansę intymnej pracy z własną nieświadomością, i to właśnie efekt jego sił

30 Minutes of the Vienna Psychoanalytic Society, Tom I-IV, oprac. H. Nunberg, E. Federn, przeł. M. Nunberg, International Universities Press, New York, 1962-1975, s. 259-269.

31

Tamże, s. 260. 
wytwórczych miał stać się przedmiotem namysłu analityka. Metoda zaproponowana przez Grafa, i zaaprobowana przez Freuda, miała doprowadzić do stworzenia teorii kreacji artystycznej ${ }^{32}$.

Podczas dyskusji negatywnie o patografiach wypowiadał się Otto Rank. Twierdził, że dzięki tworzeniu, poeta wchodził w rolę analityka i poddawał się samoobserwacji i autoanalizie. Z kolei lekarz, przyjmując rolę patografa, nie doceniał samowiedzy twórcy oraz pozostawał głuchy na jego głos. Odwrotnie niż proponowali Graf i Rank, psychografie Sadgera charakteryzowały się obszernymi fragmentami przepisanymi z dzienników i szkiców autobiograficznych, w których język autora splatał się z wypowiedziami samego poety. Uczeń Freuda był jedynym obecnym podczas dyskusji, który sprzeciwił się propozycjom Grafa oraz odrzucił twierdzenie Freuda o możliwości psychoanalitycznego wyjaśnienia procesu twórczego. W jego ujęciu psychografia powinna bazować na materiale biograficznym i prowadzić do postawienia precyzyjnej diagnozy psychiatrycznej. Podkreślił również, że swe prace pisał wyłącznie z lekarskiej ciekawości i nigdy nie próbował wchodzić w rolę badacza literatury, dla którego związek między życiem i dziełem twórcy był zasadniczy.

W 1908 roku Sadger opublikował studium Konrad Ferdinand Meyer. Eine pathographisch-psychologische Studie. Kilka miesięcy wcześniej, 4 grudnia 1907 roku na spotkaniu Środowego Towarzystwa Psychologicznego Wilhelm Stekel apelował do autora, aby nie składał tekstu do druku³. Sam Freud również nie szczędził mu krytyki. Według twórcy psychoanalizy metoda przyjęta przez Sadgera była zła, a samo studium nie wnosiło nic nowego do wiedzy o poecie. Zarówno odczyt, jak i późniejsza publikacja sprowadzały się do obszernego szkicu biograficznego, w którym autor rozpoczynał od przedstawienia dzieciństwa i młodości Meyera, opisywał okres dojrzałości oraz czas starzenia się i choroby. W pierwszym rozdziale Sadger zrekonstruował genezę choroby psychicznej Meyera, upatrując jej źródeł w historii jego przodków ${ }^{34}$. Nie pominął również szczegółowej analizy okresu infantylnego poety,jego pierwszych doświadczeń seksualnych oraz relacji z rodzicami i rodzeństwem ${ }^{35}$. W jego

32 Tamże, s. 264.

33 Tamże, s. 255-256.

I. Sadger Konrad Ferdinand Meyer, s. 6-23.

35

Rozwiniętych przede wszystkim w rozdziale Der Dichter und seine Mutter bis zum ersten Aufenthalt in der Irrenanstalt. Die Belastungssymptome der Pubertät oraz Bis zum Tode der Mutter -zob. tamże, s. 9-28. 
interpretacji w rozwoju poety najważniejszą rolę odegrała silna więź z matką. Niespełniona miłość do niej miała wpłynąć na rozwinięcie się u niego pragnień homoseksualnych oraz doprowadzić do seksualnej impotencji. Sadger opierał się na danych biograficznych pozyskanych z autobiograficznych wypowiedzi Meyera, a także na studium autorstwa szwajcarskiego historyka literatury Adolfa Freya z 1900 roku $^{36}$. W swej patografii starał się połączyć język psychoanalizy (analiza relacji rodzinnych) z perspektywą XIX-wiecznej psychiatrii (utrzymanie tezy o dziedziczności chorób psychicznych). Próba zespolenia obu perspektyw wywołała sprzeciw Freuda, który skrytykował chęć tłumaczenia psychologii każdego kolejnego twórcy wedle jednego schematu ${ }^{37}$ i odrzucił pojęcie Belastungneurose, zaproponowane przez Sadgera w jego pierwszym odczycie na określenie neuroz przekazywanych dziedzicznie $^{38}$. Interpretację psychologii Meyera neurolog przeprowadził analogicznie do modelu zastosowanego wcześniej w psychografii Lenaua. Podstawą analizy we wcześniejszym studium była intymistyczna twórczość poety, przede wszystkim korespondencja z Sophią Löwenthal, której fragmenty psychoanalitycy odczytali wspólnie w trakcie spotkania. Według Sadgera choroba psychiczna i śmierć poety w zakładzie psychiatrycznym związane były, podobnie jak u Meyera, z niezaspokojoną miłością do matki, tłumionym homoseksualizmem, strachem przed nieposłuszeństwem (złamaniem prawa moralnego) oraz śmiercią. Szukając przyczyn paraliżu poety, Sadger wskazywał zarówno na wpływ dziedziczności, jak i szkodliwą rolę masturbacji39.

5 maja 1909 roku psychoanalityk zaprezentował kolejne studium psychograficzne, tym razem poświęcone Kleistowi, opublikowane jeszcze w tym samym roku. Zdiagnozował w nim poetę jako sadystę i narcyza ${ }^{40}$, co po raz kolejny spotkało się z niechęcią pozostałych członków Wiedeńskiego Towarzystwa Psychoanalitycznego oraz ponowną krytyką Freuda. Tym razem jednak twórca psychoanalizy nie odniósł się do treści analiz Sadgera, lecz przedstawił własną koncepcję pisania psychologicznych portretów twórców. Zauważył, że psychografia wymaga innego języka niż podpowiadał słownik ówczesnej psychiatrii. Według autora Totemu i tabu teksty Sadgera

\footnotetext{
36 A. Frey Conrad Ferdinand Meyer. Sein Leben und seine Werke, Cotta, Stuttgart-Berlin 1919. 
odrzucały czytelników, bowiem traktował on swych bohaterów wyłącznie jako przypadki patologiczne. Kiedy pisał o ich seksualności, nie potrafił powstrzymać się od moralnego osądu, a tym samym dystansował się od przedmiotu własnych badań. Podejście Freuda do psychografii wyróżniało się wyraźnym odejściem od spojrzenia klinicznego. Apelując do swych współpracowników, aby, pisząc, powstrzymywali się od „moralnego patosu”, zrezygnował z przypisanej lekarzowi pozycji wiedzy/władzy ${ }^{41}$. Inaczej niż pochodzący z Nowego Sącza lekarz, Freud nie stawiał granicy między sobą a przedmiotem analizy. Kiedy w artykule Pisarz i fantazjowanie zastanawiał się nad istotą pracy poety, jego namysł nad psychologią artystycznej kreacji nosił znamiona refleksji autobiograficznej ${ }^{42}$. Na krótko przed powstaniem studium o Leonardzie zapisał:

Gdybyśmy chociaż mogli znaleźć u siebie czy u nam podobnych ślady aktywności w jakiś sposób podobnej do uprawiania sztuki poetyckiej! Badanie tego pozwoliłoby nam mieć nadzieję na położenie pierwszych podwalin pod wyjaśnienie natury pracy poety. I w rzeczy samej, mamy niejakie perspektywy w tym względzie - przecież już sami poeci lubują się w zmniejszaniu dystansu pomiędzy specyfiką swej pracy i uniwersalną naturą ludzką, często więc zapewniają nas, że w każdym człowieku tkwi poeta i że ostatni poeta zginie dopiero wtedy, gdy umrze ostatni człowiek. $^{43}$

To właśnie analiza dzieł literackich i poszukiwanie źródeł pracy twórczej zbliżały psychoanalityka do fantazjującego pisarza. Freud nie skrywał uwielbienia dla badanych przez siebie twórców. Jak zauważa Didier Anzieu, twórca psychoanalizy nie tylko fascynował się dziełami i historią życia Goethego czy Leonarda, lecz także identyfikował się z nimi ${ }^{44}$. Z kolei Sadger w większym stopniu niż pisarzem chciał pozostać analitykiem i biografem. Przez długi czas głównym celem było dla niego diagnozowanie chorego twórcy oraz dostarczenie psychiatrii nowego materiału do badań.

\footnotetext{
41 Tamże, s. 224-225.

42 S. Freud Pisarz i fantazjowanie, w: tegoż Sztuki plastyczne i literatura, s.149.

43 Tamże, s. 145 .

44 D. Anzieu Le corps de l'œuvre. Essais psychanalytiques sur le travail créateur, Gallimard, Paris 1981, S. 24-43.
} 


\section{Psychoanalityk jako pisarz i literaturoznawca}

W pierwszych miesiącach 1912 roku uczeń Freuda zajmował się psychografią Hebbela. Odczyty na spotkaniach Środowego Towarzystwa Psychologicznego wykorzystał jako podstawę dwóch artykułów opublikowanych później na łamach „Imago", psychoanalitycznego pisma w całości poświęconego literaturze. Oba teksty - Von der Patographie zur Psychographie ${ }^{45}$ oraz Über das Unbewußte und die Träume bei Hebbe ${ }^{46}$ - dowodzą zmiany w podejściu Sadgera do psychologii twórców. Już wówczas psychoanalityk zrezygnował z nazwy „patografia”, którą zastąpił terminem „psychografia”. W artykule Von der Patographie zur Psychographie wyłożył podstawy stworzonego przez siebie nowego gatunku, opartego na odmiennych założeniach teoretycznych (przede wszystkim innym postrzeganiu szaleństwa i granic między zdrowiem a chorobą) niż było w pracach Moebiusa czy Lombroso.

W odróżnieniu od swych wcześniejszych publikacji Sadger podkreślił, że poeci często rozumieli tajniki ludzkiej psychiki lepiej niż psychiatrzy. Dopiero odkrycie nieświadomości umożliwiło tym ostatnim stworzenie wartościowych psychobiografii twórców ${ }^{47}$. Dzięki refleksji psychoanalitycznej, pisał, w krótkim czasie powstały nowatorskie prace poświęcone pisarzom i wykreowanym przez nich postaciom literackim. Sadger sądził, że choć Lombroso zasadnie opisał łatwość z jaką geniusz przeradza się w stan patologiczny, dopiero Freud zbliżył się do wyjaśnienia zagadki artystycznej kreacji - problemu nurtującego samych poetów ${ }^{48}$. W tekście psychoanalityk krytykował własne patografie, którym poświęcił ponad dwie dekady swej pracy naukowej. Przyjmując uwagi autora Totemu itabu, stwierdził, że w opisie psychograficznym życie i dzieło twórcy powinny zostać połączone. Psychograf w swej refleksji musi pochylić się nad związkiem miłosnego życia twórcy oraz nie uciekać od analizowania jego dzieł pod kątem pragnień kazirodczych i homoseksualnych. Zgodnie z uwagą Freuda, że: „biografowie usuwają z fizjonomii swego bohatera wszelkie cechy indywidualne, zacierają ślady walk, jakie za życia stoczył z wewnętrznymi i zewnętrznymi oporami, nie tolerują w nim

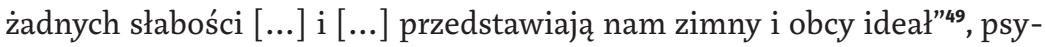

\footnotetext{
45 I. Sadger Von der Pathographie zur Psychographie, "Imago" $1912 \mathrm{nr} 1$ (2), s.158-175. 
chograf powinien podjąć namysł nad kwestiami powszechnie uznawanymi za wstydliwe i niemoralne - nie po to, aby umniejszyć poetę, lecz lepiej pojąć jego dzieło ${ }^{50}$.

Dla Sadgera największą inspiracją w owym czasie pozostawał tekst Freuda Leonarda da Vinci wspomnienie z dzieciństwa opublikowany w 1910 roku. Podczas dyskusji poświęconej prezentacji artykułu uczeń Freuda wyraził zachwyt nad odkryciami twórcy psychoanalizy oraz wprowadzoną przez niego metodą analizy ${ }^{51}$. W eseju poświęconym włoskiemu artyście materiał biograficzny (analiza dziecięcego wspomnienia związanego z sępem) pod względem objętości równał się interpretacji wybranych dzieł malarskich jego autorstwa. Kompozycja tekstu wpłynęła na Sadgera, który w późniejszych artykułach wprowadził analizę poszczególnych dramatów Hebbela ${ }^{52}$. Zmienił się również jego stosunek do poety - z patologicznego przypadku stał się samoświadomym twórcą a także przedmiotem fascynacji autora. Wszechwiedzący głos lekarza ustąpił miejsca autorefleksji Hebbela, a podejście psychografa do analizowanego upodobniło się do relacji Freuda z Leonardem, gdzie przedmiot i podmiot tekstu zbliżają się do siebie ${ }^{53}$.

Pisanie psychologicznych portretów poetów wymagało nie tylko wiedzy psychiatrycznej, lecz i erudycji. Najobszerniejsza z psychografii autorstwa Sadgera, ponad dwustustronicowe studium analityczne Friedrich Hebbel. Ein psychoanalytischer Versuch, zaskakuje nie tylko objętością, lecz i obeznaniem autora (będącego lekarzem neurologiem, nie zaś historykiem literatury) z dziełami niemieckiego dramaturga. Szczególna zdolność psychoanalityków do syntetyzowania refleksji o kulturze z naukową precyzją w dużej mierze związana była z odebraną przez nich edukacją. Szkolna droga Freuda nie różniła się od edukacji odebranej dziesięć lat później przez Sadgera. Obaj psychoanalitycy byli uczniami Realgymnasium, wówczas eksperymentalnej placówki edukacyjnej spajającej dwa wcześniejsze modele: Gymnasium i Realschule. Głównym jej założeniem było położenie większego nacisku na nauki ścisłe i techniczne, a nie na wykształcenie klasyczne (jak w przypadku

50 jego poezję oraz dramaty. Judycie i Marii Magdalenie Hebbela psychoanalityk poświęcił dwa
osobne rozdziały - zob. I. Sadger Friedrich Hebbel. Ein psychoanalytischer Versuch, s. 251-275, 320-374. 
Gymnasium). Niemniej zarówno Freud, jak i Sadger uczęszczali na zajęcia z języków klasycznych i nowożytnych (greka, łacina, niemiecki, francuski, dodatkowy angielski) oraz z filozofii z podstawami psychologii, wykładanej podług teorii Friedricha Herbarta ${ }^{54}$. W 1849 roku w Austro-Węgrzech przeprowadzono reformę szkolnictwa, dotychczas opartego na modelu pedagogiki jezuickiej (greka ograniczona do minimum na rzecz łaciny). Po 1849 roku wiedza o kulturze i języku starożytnej Grecji stała się istotnym elementem edukacji aż do kolejnej reformy w 1908 roku ${ }^{55}$. W drugiej połowie XIX wieku zarówno w Niemczech, jak i w Austro-Węgrzech dominowały już dwa osobne modele myślenia o nauce. Jak zauważa Jacques Le Rider, nastąpiło wówczas oddzielenie nauk ścisłych od wiedzy o kulturze i literaturze, opartej na wykształceniu klasycznym oraz nowoczesnej filologii (ukształtowanej po reformie Ulricha von Wilamowitza-Moellendorffa oraz Theodora Mommsena $)^{56}$. Chociaż Realgymnasium stawiało nacisk na nauki ścisłe, Le Rider dodaje, że to właśnie tam Freud zapoznał się z kulturą starożytną, filozofią i psychologią i zafascynował się nimi ${ }^{57}$. Sadger, tak jak twórca psychoanalizy, był człowiekiem obu kultur, zdolnym zarówno do refleksji literaturoznawczej, jak i posługującym się językiem nauk ścisłych ${ }^{\mathbf{5 8}}$.

Studium o Hebbelu pozostaje najobszerniejszą a zarazem najbardziej wnikliwą psychografią autorstwa Sadgera. Mimo że we wstępie autor podkreślił, że jego dzieło nie jest biografią poety ${ }^{59}$, nawet pobieżna lektura pozwala stwierdzić coś zgoła przeciwnego. Dzieło zostało podzielone na dwie części, z czego wyłącznie druga stanowi studium psychoanalityczne, głównie poświęcone analizie snów, związku nieświadomości z procesem twórczym oraz symbolice erotycznej w poezji i dramatach niemieckiego pisarza. W pierwszej części autor przedstawił kolejne etapy życia Hebbela - jego dzieciństwo, młodość i okres związku z Elise Lensig ${ }^{\mathbf{6 0}}$; podjął również kwestię dziedziczności

54 O wpływie Herbarta na Freuda - zob. L. Karpińska Psychologiczne podstawy freudyzmu, w: Psychoanaliza w Polsce, oprac. L. Magnone, Kronos, Warszawa 2016, s. 29-45.

58 Tamże, s. 63.

60 Tamże, s. 125-196. 
choroby psychicznej poety ${ }^{61}$. Sadgera szczególnie interesowały szkice autobiograficzne oraz zapiski Hebbela o własnych marzeniach sennych. Powołując się na losy i biografię pisarza, dowodził „rodzinnego kompleksu” (Familienkomplex), sadyzmu i narcyzmu poety, widocznych w całej jego twórczości62. Chociaż psychografia nie miała być traktatem estetycznym ani historią życia twórcy, powinna czerpać z obu gatunków. Psychoanalityk skoncentrował się na skrupulatnej analizie autorefleksyjnych wypowiedzi Hebbela, w rezultacie niewiele miejsca poświęcając własnym interpretacjom. Istotna była dla niego myśl poety, zgodnie z którą największym obowiązkiem człowieka zajmującego się pisaniem powinno być dostarczanie materiału do swej przyszłej biografii ${ }^{63}$. Praktyka codziennego zapisu - notowanie uwag o sobie, bieżących refleksji i spostrzeżeń - miała według Hebbela służyć jako źródło inspiracji dla przyszłego biografa.

Praca psychoanalityka nad jego ostatnią psychografią przebiegała wedle następującego schematu: rozpoczynał od lektury dzieł poety (przede wszystkim z zakresu intymistyki), na ich podstawie rekonstruował jego biografię, następnie wybierał fragmenty z dzienników, które analizował we własnym tekście, wykorzystując narzędzia psychoanalityczne. Następnym etapem była prezentacja materiałów na posiedzeniach Środowego Towarzystwa Psychoanalitycznego, wprowadzenie poprawek do tekstu i złożenie go do publikacji. Łatwo dostrzec, że w pierwszym etapie pracy nad psychografią rola Sadgera w dużej mierze polegała w na wnikliwej lekturze dzieł poety, a więc na usłyszeniu jego głosu i na podjęciu próby interpretacji jego słów. W tym punkcie praca psychografa nie różniła się od zadania psychoanalityka, rozpoczynającego analizowanie od wysłuchania historii opowiedzianej przez pacjenta. Tak jak Eugen Breuer w przypadku Anny O. czy Freud w rozmowie z Kathariną C., w pierwszej części studium Sadger starał się jak najwierniej oddać sposób mówienia i opowiadania analizowanego ${ }^{64}$. Dopiero później przystąpił do przekształcania zebranego materiału we własną narrację. Dokładnie tak jak pisarz, stworzył bohatera swego tekstu, nadając materii jego życia spójną i linearną formę, właściwą dla gatunku biografii.

61 Zwłaszcza rozdział Wanderjahre (Sexualität, Charakter, 1. Teil). Belastung - zob. tamże, s. 95-124.

62 Tamże, s. 251-275.

63 F. Hebbel Dzienniki, przeł. K. Irzykowski, Czytelnik, Warszawa 1958, s. 9, 14.

64 Por. S. Freud, J. Breuer Studia nad histeriq, przeł. R. Reszke, KR, Warszawa 2008, s. 25-46, 111-122; I. Sadger Friedrich Hebbel, s. 3-250. 
Pisanie psychologicznych studiów poetów umożliwiło Sadgerowi samorealizację na polu zarówno medycyny, jak i literatury. Psychobiograf, tak jak analityk słuchający opowieści pacjenta, był jednocześnie lekarzem badanego twórcy (w roli pacjenta), jak i kreującym jego historię pisarzem. Na pięć dzieł, opublikowanych przez Sadgera w ciągu niespełna trzydziestu lat członkostwa w Wiedeńskim Towarzystwie Psychoanalitycznym (1906-1933), tylko jedna miała charakter stricte kliniczny i dotyczyła seksualności ${ }^{65}$. Pozostałe cztery publikacje wiedeński neurolog poświęcił poetom oraz ich twórczości. Choć psychografie jego autorstwa nie zyskały uznania, a dziś najczęściej są pomijane przez badaczy zajmujących się historią psychoanalizy ${ }^{66}$, nie tylko oświetlają one związek freudyzmu z literaturą, lecz dowodzą też nierozerwalnej więzi łączącej psychoanalityczne teoretyzowanie z pisarską aktywnością i procesem twórczym. W przypadku Sadgera, wykorzystującego stworzony przez siebie schemat interpretacyjny w każdej kolejnej patografii, uwagę przykuwa nie tylko treść jego dzieł, lecz i sama praktyka pisania biograficznego. W psychografiach jego autorstwa nie chodziło wyłącznie o efekt - kompletną psychoanalizę twórcy, lecz o wartość nieustannie ponawianego schematu studiowania i opisywania psychologii poetów. Sadger, jedyny z najbliższych współpracowników Freuda, który w tak dużym stopniu poświęcił się psychografiom, do perfekcji opanował warsztat biografa. Spod wierzchniej warstwy jego dzieł teoretycznych wyłania się jednak surowy materiał, dopiero kształtowany przez pisarza. To właśnie w nim dojrzeć można zarówno trud, jak i przyjemność czerpaną z lektury tekstów innych autorów, zbierania i porządkowania materiałów, notowania, a wreszcie samego pisania - praktyki, która, oprócz prowadzonych analiz oraz pracy klinicznej, wypełniła większą część życia psychoanalityka.

65 I. Sadger Die Lehre von den Geschlechtsverirrungen. (Psychopathia sexualis) auf psychoanalytischer Grundlage, Deuticke, Leipzig-Wien 1921. jedynie studium poświęcone Hebbelowi i późniejszą biografię Freuda - zob. A. Dundes Introduction, w: I. Sadger Recollecting Freud. 


\section{Abstract}

\section{Agnieszka Więckiewicz}

UNIVERSITÉ PARIS SORBONNE

UNIVERSITY OF WARSAW

The Analyst as a Writer and Biographer: IsidorSadger's Work in Psychobiography and the Psychoanalysis of Literature

The psychoanalyst Isidor Sadger, one of Freud's earliest and closest students, produced a series of works in psychobiography. Więckiewicz portrays him and his work to examine the relationship between literary scholarship and Freudian psychoanalysis, and to demonstrate that Sadger influenced Freud and his works on literature. Discussions of the Wednesday Psychological Society indicate the broad context in which Freud produced his key works on artists, writers and their works. Drawing on Michael Foucault, moreover, Więckiewicz proposes an alternative reading of nineteenth-century medical discourses. Her goal is to show that the earliest psychoanalysts consciously distanced themselves from the language of nineteenth-century psychiatry in order to develop new models for interpretation and writing.

\section{Keywords}

psychoanalysis, Isidor Sadger, psychography, pathography, psychiatry 